\title{
Section:
}

\section{HISTORY AND MODERNITY}

\author{
THE ROMAN CATHOLIC MONASTIC ORDERS \\ IN EASTERN GALICIA IN THE EARLY $20^{\mathrm{TH}}$ CENTURY
}

\author{
OLEG ZHERNOKLEYEV
}

\begin{abstract}
This study involves the analysis of the overall quantitative, structural and sociodemographic characteristics of the Roman Catholic monastic Orders in Eastern Galicia as a part of the Galician Crown land of Austria-Hungary in the early 20 $0^{\text {th }}$ century. In the second half of the $19^{\text {th }}$ century, the Roman Catholic monastic communities renewed their activity after a period of decline in the epoch of Enlightenment. The analysis indicates two features that characterize the contemporary Galician monastic Orders - a significant predominance of female members and active social work among the population of the region. Quantitatively, the Roman Catholic monastic structures considerably exceeded those of the Greek Catholic Church.
\end{abstract}

Keywords: monastic Orders, monasticism, monks, nuns, Roman Catholic Church, Galicia.

Throughout many centuries of Modern history, the multiethnic nature of Galicia was a factor behind the long-term presence of various structures of the Roman Catholic Church in the region, the Catholic monastic Orders in particular, whose members by far outnumbered those of the Greek Catholic institutions. The qualitative aspect of the phenomenon was of no less importance - monks and nuns as consecrated persons often were a much more effective instrument of apostolic and charitable activity of the Church than secular priests, married and laden with families and social responsibility.

The Ukrainian scholars researched into the history of some Catholic monastic Orders (especially the Franciscans and the Dominicans $[1 ; 2 ; 3]$ as the largest and the most active ones) and studied the main periods in the development of Roman Catholicism in Ukraine and in its western region in particular [4; 5]. Still, the social phenomenon of the Roman Catholic monasticism in Galicia has not been the subject of a detailed investigation. In Polish historiography, the matter received much more attention $[6 ; 7 ; 8]$. The analysis of the issue from the perspective of the Ukrainian historical science is important and necessary for many reasons, one of them being accusations regarding Polonization of the local Ukrainian population supported by the Roman Catholic Church and its monastic Orders [9, p. 121, 122, 124-125]. This problem has hardly been examined in the Ukrainian historical and religious studies; thus the objective of this research is to analyze general quantitative, structural, and social demographic characteristics of the Roman Catholic monastic Orders in Eastern Galicia as a part of the Galician Crown land of the Habsburg Monarchy in the early $20^{\text {th }}$ century (before World War I).

There were at least two main factors behind the appearance of the Roman Catholic monasticism in Galicia. The first one was the active missionary work of the Mendicant Orders (in South-Western Rus, they date back to the mid-13 ${ }^{\text {th }}$ century [10; 11]). The other important factor, especially in the Modern period, was the presence of a large Polish population, who professed Roman Catholicism, on the 
Ukrainian territories of Galicia. In the late $19^{\text {th }}$-the early $20^{\text {th }}$ century, there was also the German segment in Galicia, though not so large as the Polish one; it should be taken into account that a considerable part of the German population was Protestant.

In 1900, the total population of the Galician Crown land of Austria-Hungary was 7.3 million people [12, p. 10-11]. The land was informally divided into Eastern (Ukrainian) Galicia, its centre being Lviv (Lwów), and Western (Polish) Galicia, with Kraków as its historical, political, and spiritual centre. The boundary between the two parts roughly coincided with the ethnographic boundary between the Poles and the Ukrainians. Eastern Galicia comprised over two-thirds of the territory and the population of the Crown land; Western Galicia, one third. The capital of the whole Crown land was Lviv, hence the importance of Eastern Galicia for the Poles, who strived to retain their hegemony in the region, especially against the background of a strong rise in the Ukrainian national movement. In this contest, the role of religion and the Church should not be underestimated.

According to the official statistics of 1900, more than one million residents of Eastern Galicia (about 23 percent of the population) professed Roman Catholicism [13, p. 306], almost 800 thousand Roman Catholics lived in the rural communities (21 percent of the rural population) [14, p. 190].

The Polish population concentrated mostly in the landed-gentry estates, towns, and cities. In 1900, 196 thousand people lived in more than three thousand estates, 81 thousand of them were Roman Catholics (42 percent) and 65 thousand, Greek Catholics (33 percent) [15, p. 74-75]. Over one third of the town and city population of Eastern Galicia was Polish, the Ukrainian segment being considerably smaller. For example, in 58 towns and cities with the population over five thousand residents in 1900, there were 33 percent of Roman Catholics, 27 percent of Greek Catholics, 39 percent of Jewish people; in the seven biggest cities (over 20 thousand residents), 44, 19, and 36 percent respectively [15, p. 74-75]. In Lviv in 1900, there lived 101.3 thousand Roman Catholics, 56.8 thousand Jewish people, and only 34.5 thousand Greek Catholics [16].

According to Yaroslav Dashkevych, certain mythologems were characteristic of the Galician Poles' mentality, including the fictitious right to the reconstruction of Poland within the 'historical boundaries', the Polish model of Catholicism as the outpost of Christianity against barbarism (Orthodoxy and Uniatism alike), the idea of 'enlightenment' - bringing Western culture to uneducated Ukrainians, and the idea of noble superiority over them. The ethic mythologems resulted in the formation of a specific mentality [17]. At the same time, the turn of the century witnessed the formation of the mentality, spiritual and political culture common to the Poles of the contemporarily divided Poland [18, p. 174].

It is obvious that the Roman Catholic population of Eastern Galicia cannot be identified with the Polish one. For example, according to the data provided by a Ukrainian social and political activist, journalist, and scientist Volodymyr Okhrymovych, in 1900 at least 193 thousand Ukrainians were Roman Catholic (so-called Latins) [19; 20].

On the church map of the contemporary Habsburg Monarchy, the Galician Crown land was represented by four Roman Catholic Dioceses: those of Lviv, Przemyśl, Tarnów, and Kraków [21, p. 72-73]. The Ukrainian part of Eastern Galicia was mainly under the Lviv Diocese and partly, under the Przemyśl Diocese. At the same time and on the same territory, there functioned the Metropolis of the Greek Catholic Church - the Lviv, the Przemyśl, and the Stanyslaviv Dioceses. In this article, I will focus on the activity of the monastic Orders within the boundaries of the Lviv Archdiocese of the Roman Catholic Church and compare it, wherever possible, with the corresponding Lviv and Stanyslaviv Dioceses of the Greek Catholic Church (excluding Bukovyna), though I am fully aware of the relativity and conditionality of such an approach.

The state policy in the age of Enlightenment caused the decline of the Roman Catholic monastic Orders and their quantitative reduction; in Galicia and the Polish lands that were part of the Russian Empire, their revival started in the second half of the $19^{\text {th }}$ century. The process involved (1) the restoration of the old Orders, (2) the foundation and quick spread of new monastic communities, (3) increased social activity of monks and nuns in the spirit of the teaching of Pope Leo XIII (years of Pontificate 1878-1903) and the development of the Roman Catholic Church's social doctrine 
[22, p. 13, 22, 51-52]. Catechesis of children and young people, parish work, work at people's schools and hospitals, running various charity organizations and educational establishments for orphans and children of low-income families were the attributes of everyday life and activity of the Roman Catholic monks and nuns in Galicia [23, p. 16, 48, 82-83; 24].

According to the Shematyzms and the official information provided by the Church, in the Lviv Archdiocese of the Roman Catholic Church at the end of 1898, there were 35 monasteries* housing 357 persons (including 185 priests) and 118 convents" housing 1045 nuns. At the same time, there were only nine monasteries (48 monks and brothers, including 32 priests) and two convents (26 nuns) of the Greek Catholic Church on the same territory [25, p. 67].

At the end of 1911, according to the new Shematyzms and the information provided by the Galician Vicegerency, the overall picture changed: the Lviv Archdiocese of the Roman Catholic Church already had 54 monasteries housing 496 persons (including 225 priests) and 246 convents with 1714 nuns. Taken together, this amounted to 300 monastic houses and 2210 monks and nuns. As to the Greek Catholic Church, it had 11 monasteries (78 monks, including 26 priests) and 28 convents with 196 nuns [26, p. 63]. The statistics of the Przemyśl Dioceses of the Roman Catholic Church and the Greek Catholic Church (with about the same number of believers) won't significantly change the picture - the number of monks and nuns of the Roman Catholic monastic Orders by far exceeded that of the Greek Catholic ones.

The analysis of the early $20^{\text {th }}$ century church statistics of Galicia clearly shows that the monastic Orders had a more important place and played a more important role in the local structures of the Roman Catholic Church than in those of the Greek Catholic Church. In all the four Roman Catholic Episcopates, there were, on average, 2.3 thousand faithful to one pastor (2.6 thousand in the Kraków and the Przemyśl Dioceses); while in the Metropolis of the Greek Catholic Church, 1.6 thousand. As to the members of the monastic Orders, the ratio was quite different. There was one consecrated person to 634 Roman Catholics; while with the Greek Catholics, the ratio was one to 6331 believers [26, p. 63]. By my count, in the whole Galician Crown land, the Roman Catholic Church had ten times more monasteries and convents, and twenty times more monks and nuns than the Greek Catholic.

A contemporary Polish historian and economist F. Bujak maintained that the great number of monasteries and convents partly compensated for the lack of secular clergy in the Roman Catholic Church as compared to the Greek Catholic Church. He gave the example of about two thousand Ukrainian churches vs. 312 Roman Catholic churches in the Lviv Archdiocese and drew a conclusion that there were not near enough Roman Catholic priests and churches, that the Latin parishes were too spreading, and a Polish farmer had to cover a long distance (two or three miles) to get to the nearest Roman Catholic church; the Greek Catholic churches were in almost every village, so often convenience was a key consideration.

According to F. Bujak, there were 110 percent more Greek Catholic parishes and 32 percent more Greek Catholic secular clergy than their Roman Catholic counterparts. In fact, the researcher gave it as a reason why the Poles worshiped God according to the Greek Catholic rite, thus getting denationalized; he maintained that in order to improve the situation and to overcome existing drawbacks (from the perspective of the Polish 'state of possession'), it was necessary to double the number of parishes and to triple the number of the Roman Catholic churches [15, p. 77]. On the other hand, all that enhanced the social role of the Roman Catholic monastic Orders in the Crown land, especially in its eastern part.

The analysis of the structural and social aspects of the Roman Catholic monastic Orders in Galicia indicates some interesting tendencies.

The number of nuns exceeded that of monks, though the phenomenon was not exclusively characteristic of the Galician monastic Orders. For example, in Cisleithania (the Austrian part of the Habsburg Dual Monarchy) in 1910, there were 640 monastic houses occupied by men (over 11 thousand monks) and 2316 women's monastic houses (27.4 thousand nuns) [21, p. 120-121]. The above

\footnotetext{
${ }^{*}$ For the purpose of this article, the term monastery refers to a place of residence occupied by a community of monks; the term convent, to that occupied by a community of nuns.
} 
statistical data show that in Galicia, the proportion of females was even larger than in Cisleithania on average.

The 1905 Shematyzm of the Lviv Archdiocese of the Roman Catholic Church gives us a clear idea about the inner structure of the Roman Catholic monastic communities in the early $20^{\text {th }}$ century Eastern Galicia, of their distribution among the Orders and Congregations in particular. For example, in the female communities of consecrated and apostolic life, there prevailed the nursing Sisterhood of St. Vincent de Paul (286 nuns). The Congregation had 27 centres, the biggest ones were in Lviv (six houses, 130 Sisters all told), Mariiampil (12 Sisters), Rozdil (12), Bilyi Kamin (11), Chortkiv (11), Budaniv (10), Zaliztsi (10), and in Stanyslaviv, Ternopil, Rohatyn, Burshtyn and other cities, towns, and villages [27, p. 217, 222-231]. The Sisters' main occupation was nursing the sick in the hospitals and teaching orphans.

The Congregation of the Sisters Servants of Mary Immaculate (236 Sisters all told) had the greatest number of centres (65). However, all of them were small - three or four Sisters at each house on average [27, p. 244-253]. Another large Congregation was the Franciscan Sisters of the Family of Mary (27 houses, 174 Sisters, including novices - girls and women who had been received into the Congregation for a period of probation before taking vows). The Franciscan Sisters worked mainly at people's schools. Except for Lviv (six houses, 68 nuns and 26 novices), the Franciscan Sisters' centres had, on average, three to five nuns [27, p. 257-265].

The female branch of the Roman Catholic monastic Orders in Eastern Galicia was also represented by the Benedictines, the Carmelites, the members of the Franciscan and the Dominican Regular Third Orders, and a number of other communities. For example, the above Shematyzm provides data concerning the three communities of the Sisters of the Regular Third Order of St. Francis - the Congregation of Saint Joseph, the Congregation of Our Lady of Sorrows, and Congregation of the Sisters of Saint Felix of Cantalice (popularly called the Felician Sisters). Since 1882, the first one had been running a workhouse for the poor; and since 1884, a medical establishment for the incurably sick persons and those in need of rehabilitation in Lviv. This Congregation had several daughter monastic houses in Lviv, Lubaczów, Sokal, Zbori, Kalush (nine all told) and 83 Sisters; 63 of them, including 16 novices, served in Lviv [27, p. 254-256]. The second Congregation had two houses - in Stryj (founded in 1897), whose Sisters were educating and taking care of small children, and in Peremyshliany (founded in 1898), whose Sisters were nursing the sick in the Powit (County) hospital [27, p. 267-268]. The Felician Sisters had 16 houses, six of them were in Lviv (the first one founded in 1885), for example, an institution for the girls of low-income families and an orphanage; also there were houses in Sokal, Sniatyn, Zbarazh, Zhovkva, Belz, and other cities, town, and villages; 115 Sisters all told [27, p. 233-236].

The contemporary Third Order of Saint Dominic was quite large too, especially its female segment. For example, in the whole Cisleithania at the beginning of the $20^{\text {th }}$ century, there were 24 nuns' houses of the Third Order of Saint Dominic (355 Sisters) [21, p. 121]. According to the 1905 Shematyzm of the Lviv Catholic Archdiocese, there were two houses of the Third Order of Saint Dominic - in Rava-Ruska (founded in 1887) and in Zhuriv (1889), 12 female members all told. In the former, named after Saint Anthony of Padua, there lived eight Sisters; in the latter (Community of the Sacred Heart of Jesus), four [27, p. 243]. The source does not specify the type of their activity; judging by the educational qualification of all the Sisters ('school teacher'), we may presume that it was school education. The Sisters' last names indicate their Polish and presumably German (or Austrian) origin. They were young; only one of the Sisters was 57, the rest were under 32. In the last decade of the $19^{\text {th }}$ century, when most of them took their vows, they were 19 or 20, which means that their path was chosen quite consciously.

The most numerous male Order in Galicia was the monastic Order of St. Francis; it had three branches - the Lesser Brothers of St. Francis; the Friars Minor Conventual, commonly known as the Conventual Franciscans, Minorites; the Capuchins. In 1905, the three of them had 19 monasteries and residences with 118 priests and monks, and 51 brothers who were not ordained [27, p. 195, 272]. The largest Franciscan centres were in Lviv, Zbarazh, Sokal, and some other cities, town, and villages.

The Order of Saint Dominic's Preachers was also well represented in Galicia. In Eastern Galicia alone in 1905, there were nine Dominican monasteries - in Lviv, Pidkamin, Zhovkva, Chortkiv, 
Bohorodchany and other cities, towns, and villages housing 37 priests, eight clerics, and 33 brothers who were not ordained [27, p. 195, 198-204, 272].

Apart from the above Orders, there also functioned the Order of the Jesuits (four monasteries; 36 priests among their monks), the Order of the Carmelites (four monasteries, 17 priests), the Congregation of Missionaries of St. Vincent de Paul (seven houses, 26 priests), the Congregation of the Resurrection of Our Lord Jesus Christ (so-called змартвихвстаньц̧i - 'zmartvyhvstantsi', i.e. the members of the Resurrectionist Order of the Roman Catholic Church; one house, six priests) [27, p. 195, 272].

According to the 1905 Shematyzm, only 67 out of 263 priest-monks served at parishes; they constituted 14 percent of the parish clergy of the Lviv Archdiocese (excluding Bukovyna) [27, p. 274-275]. The rest, presumably, lived and worked in the monasteries, which, by my count, functioned in 35 villages, towns, and cities. The monasteries and convents taken together, the Roman Catholic monastic Orders were represented in at least 130 villages, towns, and cities of Eastern Galicia. In Lviv, there were at least 40 Roman Catholic monastic residences, various organizations and charitable institutions; in Stanyslaviv, seven; in Ternopil and Kolomyia, five in each; in a number of other cities, towns, and villages, several organizations and institutions in each.

Lviv was a large Catholic monastic centre; in 1914, it had 17 female monastic communities (out of 24 communities of the Archdiocese) and nine (out of 14) male ones [28, p. 290]. The peak of their activity was the beginning of the $20^{\text {th }}$ century (the pre-war period), when Jozef Bilczewski (1900-1923, venerated by the Roman Catholic Church as a saint), a patron of the poor and homeless, was ordained the Archbishop of the Lviv Archdiocese. During that period, more than one hundred new parishes were established in the Archdiocese, and three hundred Roman Catholic churches were built. The Roman Catholic Church actively supported the patriotic aspirations of the Galician Poles to sovereign statehood. During the Church Services in Lviv, they honoured the memory of those who died for the independence of the Polish state; the ceremonies were held to honour great anniversaries of the Polish national history; and young people actively participated in such events [28, p. 291].

Thus in the late $19^{\text {th }}$-early $20^{\text {th }}$ century, a relatively large share of the Poles in the population of Eastern Galicia determined a considerable number of the Roman Catholic monastic Orders in the region; in terms of quantity, they significantly exceeded the Greek Catholic monastic structures. Their most noticeable features were gender disproportion (the female segment being larger than the male one) and active social work among the population. Further research is needed to give a comprehensive analysis of the historical role of Roman Catholicism in Galicia.

\section{REFERENCES}

[1] Сінкевич Н. Laudare benedicere praedicare. Домініканський орден на Вохині в кінціi XVI - на початку XIX cm. Кайрос, К., 2009.

[Sinkevych N. Laudare benedicere praedicare. Dominikanskyi orden na Volyni v kintsi XVI - na pochatku XIX st. Kairos, K., 2009.]

[2] Чорний М.I. Домініканський орден у Центрально-Східній Європі в XIII - першій половині XV ст. Автореф. канд. іст. наук., Аьвів, 2002.

[Chornyi M.I. Dominikanskyi orden u Tsentralno-Skhidnii Yevropi v XIII - pershii polovyni XV st. Avtoref. kand. ist. nauk., Lviv, 2002.]

[3] Стасюк A. Ordo Fratrum Minorum: утворення, становлення та організація францисканців у першій третині XIII ст. Вісник Прикарпатського університету. Історія, XV (2014).

[Stasiuk A. Ordo Fratrum Minorum: utvorennia, stanovlennia ta orhanizatsiia frantsyskantsiv u pershii tretyni XIII st. Visnyk Prykarpatskoho universytetu. Istoriia, XV (2014).]

[4] Яроцький П. (Ред.) Історія реліzії в Україні: У 10-ти т. Т. 4: Католицчизм. К., 2001. 
[Iarotskyi P. (Red.) Istoriia relihii v Ukraini: U 10-ty t. T. 4: Katolytsyzm. K., 2001.]

[5] Стоколос Н.Г. Конфесійно-етнічні трансформації в Україні (XIX - перша половина ХХ ст.). Рівне, 2003. [Stokolos N.H. Konfesiino-etnichni transformatsii v Ukraini (XIX - persha polovyna XX st.). Rivne, 2003.]

[6] Kościoły i klasztory rzymskokatolickie dawnego województwa ruskiego, T. 1-22. Międzynarodowe Centrum Kultury, Kraków, $2001-2014$.

[7] Kłoczowski J. Wspólnoty zakonne w średniowiecznej Polsce. Lublin, 2010.

[8] Kłoczowski J. (Ed.) Zakony franciszkańskie w Polsce. Kraków: Prowincjałat OO. Frantisekanów Konwentualnych Prowincji św. Antoniego i bł., 1983.

[9] See, for instance: Аужицький Г. Українська Церква між Сходом і Заходом: нарис історії Української Церкви. Свічадо, Пьвів, 2008.

[Luzhytskyi H. Ukrainska Tserkva mizh Skhodom i Zakhodom: narys istorii Ukrainskoi Tserkvy. Svichado, Lviv, 2008.]

[10] Стасюк А. Руські епізоди у францисканських наративах XIII ст. Галичина: наук. $і$ культ.-просв. краєзн. часопис, 20-21 (2012), 85.

[Stasiuk A. Ruski epizody u frantsyskanskykh naratyvakh XIII st. Halychyna: nauk. i kult.-prosv. kraiezn. chasopys, 20-21 (2012), 85.]

[11] Стасюк А. Проблема формування місіонерської діяльності Ордену Братів Менших на Русі в другій половині 30-х - на початку 40-х рр. XIII ст. Галичина: наук. $і$ культ.-просв. краєзн. часопис, 2223 (2013), 122-131.

[Stasiuk A. Problema formuvannia misionerskoi diialnosti Ordenu Brativ Menshykh na Rusi v druhii polovyni 30-kh - na pochatku 40-kh rr. XIII st. Halychyna: nauk. i kult.-prosv. kraiezn. chasopys, 22-23 (2013), 122-131.]

[12] Wiadomości statystyczne o stosunkach krajowych, T. XX, Zesz. II. Lwów, Krajowe biuro statystyczne, 1905.

[13] Історичні передумови возз'єднання українських земель. К., 1989.

[Istorychni peredumovy vozziednannia ukrainskykh zemel. K., 1989.]

[14] Панейко В. Національні відносини Галичини. В: Записки НТШ, Т. 84, Кн. 4, 1908. [Paneiko V. Natsionalni vidnosyny Halychyny. In: Zapysky NTSh, T. 84, Kn. 4, 1908.]

[15] Bujak F. Galicya T. 1. Kraj. Ludność. Społeczeństwo. Rolnictwo. Lwów-Warszawa, 1908.

[16] Ділі, 29 (16) серп, 1911.

[Dilo, 29 (16) august, 1911.]

[17] Дашкевич Я. Східна Галичина: етнічні відносини, національні міфи та менталітети. Україна в минулому, 6 (1994), 84-85.

[Dashkevych Ya. Skhidna Halychyna: etnichni vidnosyny, natsionalni mify ta mentalitety. Ukraina $v$ mynulomu, 6 (1994), 84-85.]

[18] Фалькович С.М. Политическая и культурная общность поляков в трех частях разделенной Польши (конец XIX - начало XX вв.). В: Хаванова О.В. (Ред.) Австро-Венгрия: интеграциионные процессы и национальная специфика. М., 1997.

[Falkovych S.M. Polytycheskaia y kulturnaia obshchnost poliakov v trekh chastiakh razdelennoi Polshy (konets XIX - nachalo XX vv.). In: Khavanova O.V. (Red.) Avstro-Venhryia: yntehratsyonnye protsessy y natsyonalnaia spetsyfyka. M., 1997.]

[19] Охримович В. Про фалшоване національної статистики при попередніх конскрипціях. Діло, 24, 26, 27 груд., 1910.

[Okhrymovych V. Pro falshovanie natsionalnoi statystyky pry poperednikh konskryptsiiakh. Dilo, 24, 26, 27 hrud., 1910.]

[20] Павлишин О. Дилема ідентичности, або історія про те, як “латинники" (не) стали українцями/поляками (Галичина, середина XIX - перша половина XX ст.). Україна модерна, 21 (2014), 179-218.

[Pavlyshyn O. Dylema identychnosty, abo istoriia pro te, yak "latynnyky" (ne) staly ukraintsiamy/poliakamy (Halychyna, seredyna XIX - persha polovyna XX st.). Ukraina moderna, 21 (2014), 179-218.]

[21] Die Habsburgermonarchie 1848-1918. Band IV. Die Konfessionen. Wien, 1995.

[22] Соцііальна доктрина Церкви (Збірник статей). Свічадо, Аьвів, 1998.

[Sotsialna doktryna Tserkoy (Zbirnyk statei). Svichado, Lviv, 1998.] 
[23] Kłoczowski J. Dzieje chrześcijaństwa polskiego, Tom II. Paryż: Editions du Dialogue, 1991.

[24] Dębowska K. Historia życia zakonnego w Polsce. Available at: http://zakonyzenskie.pl/index.php/historia/34-historia/66-historia-ycia-zakonnego-w-polsce (13.02.2016).

[25] Podręcznik statystyki Galicyi wydany przez Krajowe biuro statystyczne pod redakcya Dr. Tadeusza Pilata, T. VI, Cz. 1. Lwów, 1900.

[26] Podręcznik statystyki Galicyi wydany przez Krajowe biuro statystyczne pod redakcya Dr. Tadeusza Pilata, T. IX, Cz. 1. Lwów, 1913.

[27] Catalogus universi venerabilis cleri saecularis et regularis Archidiecesis Leopoliensis rit. lat. pro anno Domini MCMV. Leopoli, 1905.

[28] Ісаєвич Я., Литвин М., Стеблій Ф. (Ред.) Історія Аьвова: У 3-х m, Т.2. Центр Європи, Аьвів, 2007. [Isaievych Ya., Lytvyn M., Steblii F. (Red.) Istoriia Lvova: U 3-kh t, T.2. Tsentr Yevropy, Lviv, 2007.]

Address: Oleg Zhernokleyev, Vasyl Stefanyk Precarpathian National University, 57, Shevchenko Str., IvanoFrankivsk, 76025, Ukraine.

E-mail: zherno@gmail.com.

Received: 25.07.2017; revised: 15.09.2017.

Жерноклеєв Олег. Римо-католицьке чернецтво у Східній Галичині на початку XX ст. Журнал Прикарпатського університету імені Василя Стефаника, 4 (2) (2017), 34-40.

У статті розглянуті загальні кількісні, структурні та соціально-демографічні характеристики римо-католицького чернецтва Східної Галичини як складової Галицького коронного краю АвстроУгорщини на початку XX ст. Відзначається, що з другої половини XIX ст. спостерігалося відновлення діяльності римо-католицьких чернечих спільнот після періоду їх занепаду в епоху Просвітництва. Характерним для них було значне переважання жіноцтва, а також активна соціальна праця серед населення. Численне римо-католицьке чернецтво в краї значно переважало за кількісними параметрами відповідні структури Греко-катодицької церкви.

Ключові слова: чернецтво, Римо-католицька церква, Галичина. 